Beyond the Promise: A Perspective on Research in Moral Education

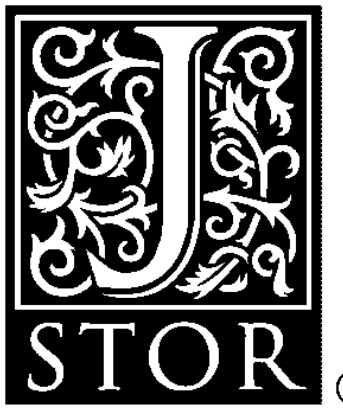

(B)

Author(s): Muriel J. Bebeau, James R. Rest, Darcia Narvaez

Source: Educational Researcher, Vol. 28, No. 4 (May, 1999), pp. 18-26

Published by: American Educational Research Association

Stable URL: http://www.jstor.org/stable/1176445

Accessed: 31/08/2008 22:00

Your use of the JSTOR archive indicates your acceptance of JSTOR's Terms and Conditions of Use, available at http://www.jstor.org/page/info/about/policies/terms.jsp. JSTOR's Terms and Conditions of Use provides, in part, that unless you have obtained prior permission, you may not download an entire issue of a journal or multiple copies of articles, and you may use content in the JSTOR archive only for your personal, non-commercial use.

Please contact the publisher regarding any further use of this work. Publisher contact information may be obtained at http://www.jstor.org/action/showPublisher?publisherCode=aera.

Each copy of any part of a JSTOR transmission must contain the same copyright notice that appears on the screen or printed page of such transmission.

JSTOR is a not-for-profit organization founded in 1995 to build trusted digital archives for scholarship. We work with the scholarly community to preserve their work and the materials they rely upon, and to build a common research platform that promotes the discovery and use of these resources. For more information about JSTOR, please contact support@jstor.org. 


\title{
Beyond the Promise: A Perspective on Research in Moral Education
}

\author{
Muriel J. Bebeau James R. Rest Darcia Narvaez
}

\begin{abstract}
Changing concerns and ideological shifts in American society produce different emphases in moral education. We argue that different approaches address different dimensions of development. If viewed as complementary rather than contradictory, we may be able to move beyond ideological and philosophical disputes to solid theory-building based on empirical findings. In proposing an action program for moral education that incorporates research, we draw upon lessons learned from the Head Start movement of the 1960s. In defining researchable variables, we recommend the Four Component Model (sensitivity, judgment, motivation, character) instead of the usual tripartite model (thinking, feeling, acting).
\end{abstract}

Educational Researcher, Vol. 28, No. 4, pp. 18-26

B eginning in the early 1980s and extending through the 1990s, we have seen a resurgence of character education, first popularized in the 1930s, as a response to a growing perception that American society is in a state of crisis, moral decay, or serious decline. The currency of the concern for basic socialization of the nation's youth is reflected in President Clinton's 1997 State of the Union Address: "Character education must be taught in our schools. We must teach children to be good citizens." Schools across the country are responding. In St. Paul, Minnesota, for example, the School Board has mandated character education for its public schools. Although the term has been appropriated for many forms of moral education, including the education of military professionals, ${ }^{1}$ the movement is largely a response to concerns with socialization of the nation's youth.

The American public is usually alarmed about some aspect of youth development, but the concerns shift from time to time. During the late 1950s, at the time of Sputnik, Americans were concerned that the next generation of Americans would not be able to keep pace with the Soviets in weapons technology. The nation was concerned that there would not be enough scientists, engineers, and mathematicians among the nation's youth to compete with the Soviets. During the 1960s and 1970s, student protests, the Civil Rights Movement, Vietnam War protests, and a vocal counter-cultural movement challenged the power structure of the country and challenged the usual assumptions of the Good Life. Also scattered throughout these years were concerns of a different sort: inner city riots, President Lyndon Johnson's War on Poverty, and particularly Operation Head Start, which focused attention on more basic questions of socialization. These concerns were not about producing enough engineers or imparting a standard conception of the American Dream. These concerns focused on circumventing the cycle of poverty and counteracting the formation of an underclass characterized by despair, crime, and wasted and unhappy lives. During the 1980s and 1990s, concerns shifted to include the consequences of ineffectual education across the continuum. Media coverage of dissolute evangelists, shady scientists, inside traders, and unethical politicians undermined our faith in the integrity of trusted authorities. Instances of corporate malfeasance (e.g., the corporate chemical spill in Bhopal, India; the corporate swindling of the Defense Department; the $\$ 2.5$ billion judgment against the A. H. Robin Company for its mishandling of problems with the Dalkon Shield; documentation of the nicotine lacing of cigarettes by tobacco companies) challenged the notion of a functional corporate conscience.

Historically, then, the American public has had concerns that run the gamut of a developmental/behavioral/ educational continuum. For a society to be worried about problems across the educational continuum (for instance, about eliminating illiteracy and about producing enough scientists) is not unusual. Although problems all along the developmental spectrum can be real and urgent, today the focus in public schooling is on failures of primary selfregulation and discipline (viz., drive-by shootings, teen pregnancy, violent crime).

Currently, national attention is on basic socialization and on reversing the growing destructiveness of youth. News articles cite alarming statistics such as the following:

MuRIeL J. BeBEAU is a professor in the Department of Preventive Sciences, University of Minnesota School of Dentistry. She specializes in professional ethical development and is Director of Education for the Center for the Study of Ethical Development at the University of Minnesota.

JAMES R. REST is a professor in the Department of Educational Psychology in the College of Education and Human Development and Research Director for the Center for the Study of Ethical Development at the University of Minnesota. He specializes in moral development theory and measurement.

DARCIA NARVAEZ is an assistant professor in the College of Education and Human Development and Executive Director for the Center for the Study of Ethical Development at the University of Minnesota. She specializes in moral cognitive processes, teacher development, and diversity issues. 
- Homicide among youth doubled from 1970-1980, then again doubled by 1987, and again doubled by 1992.

- On a typical day, over 130,000 American school children bring guns to school.

- The United States leads the industrialized world in unmarried teen pregnancies.

- The United States leads the industrialized world in drug abuse among teens.

While there might be some debate over exact figures, and even some debate about whether crime, violence, and teen pregnancies are on the rise, ${ }^{2}$ the picture is still troublesome. For many educators, the trends do not seem to indicate a normal blip within a bounded pattern of variation, but a growing problem percolating among the country's youth. Currently, attention is focused on basic socialization, though any day a catastrophe like the Chernobyl nuclear disaster or a costly debacle like the Savings and Loan scandal could shift attention to another part of the developmental spectrum. And so, while we do not wish to minimize the present concern over youth destructiveness, we do want to make the point that there are problems at all levels of education. But first, let us look at concerns about the early years of schooling.

\section{The Special Focus of Character Education}

At present, there are numerous voices that call for character education as a means for countering youth anomie and anarchy. Recent books by Lickona (1991), Wynne and Ryan (1993/1997), and Kilpatrick (1992) all start by describing the failures in the primary socialization of many of our nation's youth and then provide suggestions for direct teaching of moral values. William Bennett emphasizes the need for moral literacy. His book The Book of Virtues (1993) was on the New York Times bestseller list for nearly two years, then followed by The Children's Book of Virtues (1995a) and The Moral Compass (1995b). The political campaigns of many office seekers now emphasize the moral crisis, the breakdown of family values, America's moral decline, moral illiteracy, and the values crisis (c.f., Klein, Newsweek, 1994; Herbert, U.S. News and World Report, 1996; Iovine, Minneapolis Star Tribune, 1997). We hear about the Character Education Partnership, the character education network, the Aspen Declaration on Character Education, and the publicity campaign, Character Counts. Education magazines and journals report new initiatives for character education in schools (e.g., Educational Leadership, November, 1993). Most, but not all, of the school innovations are at the elementary school level (e.g., Boston University, 1993; Charney, 1992; Kirschenbaum, 1995). For all of these voices, the first concern is for "basic morals" - that is, in preventing youth from committing felonies and in doing irreversible harm to themselves and others.

\section{Ideological Disputes}

The recent resurgence of character education has called into question the relevance of the cognitive development approach to morality research and education. Some (e.g., Kilpatrick, 1993) regard the cognitive developmental tradition as disproved and part of the problem. For example, champions of the return of character education (Bennett, 1991; De Roche \& Williams, 1998; Kilpatrick, 1993; Wynne \& Ryan, 1993/1997) argue for a particular kind of moral education, whose focus is on the development of virtuous per- sonality traits. Instructional activities place emphasis first on moral literacy, assuming that the failure to do good is a result of not telling the child what is good. Children, it is thought, learn about virtuous deeds and actions through stories about virtuous persons, and through the use of extrinsic rewards to reinforce appropriate behavior. Proponents of the movement argue that schools already teach morality - they just need to do so more purposefully. To "reclaim our nation's schools" (Wynne \& Ryan, 1993/1997), we must return to traditional values; build community support for the traditional values; and inculcate good values, good habits, and good doctrine.

Skeptics (e.g., Kohn, 1997) argue that such direct teaching of values ignores findings from earlier efforts to influence character (Hartshorne \& May, 1928-1930), recalling the general failure of didactic approaches to positively influence behavior. Further, they argue that simple solutions, such as "telling children to be honest and work hard," ignore the accumulated evidence from social and developmental psychology, which demonstrates that much of how we act and who we are reflects our interpretation of the situations in which we find ourselves. Constructivists, like Kohn, also question whether programs that promote core values such as "obedience, respect, responsibility, and citizenship"arrived at through consensus within a community-do so at the expense of other values (empathy and skepticism) that are important to human growth and development.

In contrast to a constructivist or progressive vision of moral education, proponents of the character education movement make different assumptions about teaching and learning, have different conceptions of the cause of moral failure, and have different aims for moral education. Rest, Narvaez, Bebeau, and Thoma (1999) observe that character education (following social learning theory) champions the heteronomous side of morality (whereby children are to learn the morality that is handed down), whereas cognitive developmental psychology champions the self-initiated, self-constructed side (whereby children discover what are the possibilities and conditions of cooperation). Heteronomy and autonomy are the Yin and Yang of moral theorists. Determining whether heteronomy precedes autonomy, whether they oscillate as one moves through developmental stages, or whether both co-occur as parallel processes to produce moral thinking may be important questions for a moral psychology research agenda (as Rest et al. suggest), but we cannot cease all manner of moral education in the schools while such disputes are resolved. We must find common ground. We must create programs in the face of ideological disputes.

How does the educator create programs in the face of such controversy? How does the educational community move beyond ideological differences and the endless conflict over different approaches to moral education? How does one move beyond ideological disputes that rest upon beliefs about the sources of moral authority, disputes that are unlikely to be resolved either by research or education? We find encouragement in Guttman and Thompson's (1997) descriptions of forums for public deliberation. They argue that even when there are fundamental ideological differences, these can be discussed openly, critically, and respectfully. In response to recent criticisms of principlism (e.g., Clouser \& Gert, 1990; Toulmin, 1981), they offer deliberative universalism, a view that is committed to basic, uni- 
versal moral principles that can be employed to settle many moral issues, but leaves room for reasonable disagreement about some fundamental moral concerns (abortion, assisted suicide, etc.). Involvement in a deliberative process can achieve what Beauchamp and Childress (1994) describe as Common Morality.

Recognizing that each community will need to prioritize its own needs and base programs upon those needs, character education programs (see Damon, 1997) employ a deliberative process to gain consensus, at least on the core values for their programs. Engaging in a sustained deliberative process has the potential for "raising the standards for all our children" as Damon's title suggests, but such a process presupposes that schools engage in research to enable their community to reflect program outcomes and to modify or set new goals for student development. Critics charge that instructional strategies are not research based, and that ideological disputes within communities are simply being finessed by sticking with the high level of abstraction represented by a list of virtues-what Walzer (1983) refers to as moral minimalism. To achieve its promise, character education must engage in more than a flurry of activity punctuated by ideological rhetoric. We think there are lessons to be learned from an earlier controversy about what to do and how to do it.

\section{Lessons to Learn From Head Start}

Striking parallels can be drawn between the current emphasis on "the basics" through character education and the beginning of the Head Start preschool education program during the 1960s. First, both the movement for Head Start and the movement for character education focus on the early phase of the developmental continuum: Both address developmental beginnings; both attend to getting children on the right track. This is not to say that character education and preschool education do not have higher aspirations for their charges, but the interventions that are specifically urged are directed at preliminary socialization and are most appropriate for the early years of schooling.

Second, both movements started with grand promises to fix insidious and complex national problems. Both movements, through rhetoric, raised public expectations for dramatic reversals in problem areas in relatively short time periods. Head Start initially promised to break the poverty cycle, with an eight-week intervention and later with a year-long intervention (Zigler \& Valentine, 1979). As politicians became involved in selling the program, the rhetoric snowballed. Claims were made that Head Start would raise the IQ of poor children. And the media promoted these claims, as they fit well with the national faith in education as the key to eradicating poverty. However, the predicted backlash, from exaggerated promises which were unfulfilled, nearly destroyed the program. ${ }^{3}$ In fact, the public was outraged when the problematic evaluation of the first years of Head Start, focusing on long-term IQ effects, did not indicate a payoff (Zigler \& Muenchow, 1992). So also, if public-funded character education programs do not produce dramatic reversals in delinquency, drug abuse, teen pregnancy, and violence within a few years, the movement may be in similar trouble.

Third, both movements have been excessively driven by ideology, rather than by empirical evidence. Early on, the preschool movement was battered by the battles between environmentalists and hereditarians, and among the schools of Piaget, Montessori, and Behaviorism. However, as evaluation strategies and focus shifted over the years, programs became less ideological and more empirical. Similarly, the character education movement sets itself as the ideological triumph of teacher-directed, discipline-oriented, traditionalist approaches in opposition to child-centered, fun-oriented, modernist, and individualistic approaches (Wynne \& Ryan, 1993/1997). A lot of energy and attention are spent in defending ideological positions instead of gathering data on which methods are effective.

Fourth, both the Head Start and character education movements started with a flurry of activity, but with little systematic apparatus for tracking and recording what was happening. Initially, advocates for Head Start were perplexed as to which variables were important to study and which conditions make for success. As Zigler and Muenchow (1992) comment: "The root problem with the research and evaluation in the early years of Head Start, however, was that we did not know what to measure" (p. 51). Likewise, the character education agenda appears to have little research capability in place to find out what works with whom under which circumstances. In reviews of the research base for projects in character education, moral education, and drug and violence education, Leming (1993, 1997; Leming, HenricksSmith, \& Antis, 1997) reports that the research base to date is amazingly sparse. Identifying realistic, yet meaningful, outcomes for character education is crucial to long-term success.

Finally, it is important to avoid rhetoric suggesting that character education is a panacea for the problems of our society. ${ }^{4}$ Reflecting on the outcomes of Head Start, Zigler and Muenchow (1992) caution against the overoptimism of idealism:

Compared to poor children not enrolled in Head Start, the Head Start children fared significantly better. But compared to their wealthier peers, the Head Start children still were disturbingly behind. Indeed, as a general finding in studies on the effects of quality preschool programs, a substantial portion of the participants still require remedial education, and/or get held back a grade or more in school. Head Start cannot by itself compensate for all the bad housing, substance abuse, violence, and lack of jobs in many communities. Head Start is merely one important tool for better preparing children and families to deal with a difficult environment; it does not inoculate them against all the social ills threatening America's children and families. (p. 206)

Similarly, moral education in the schools, however well done, cannot be a remedy for the nation's ills. The problems run too deep; other changes must be made. It seems unwise to build expectations that moral education programs offer the solution to our problems with youth.

\section{Beyond Ideology: Research}

Now after 25 years, Head Start is quite different than at its inception. The ideological disputes that seemed so important 25 years ago have receded in importance. It seems that good outcomes are possible from a variety of preschool interventions, regardless of their theoretical origins. At first, general theories about human nature were useful in suggesting strategies to try and dangers to avoid. But the problems were much too complex for general theories. The 
problems of setting up preschool education or character education are far too complex to be solved by a smart person sitting in a quiet room with lots of time to think deeply, drawing deductions from general theories about human nature. We need to learn by doing, but we also need a tracking system-a research program -in place to record what is happening and to provide leads for future theory building. Then, hopefully, with the experience of conducting educational interventions, and with the experience of trying to assess their effects, we will revise many of our initial ideas and build more adequate representations about what is really involved. For instance, early in the preschool movement some "experts" thought that IQ would be an appropriate outcome variable. Now-for a variety of reasonsthe IQ variable is not considered useful in tracking the benefits of preschool education (Zigler \& Valentine, 1979). Rather, right grade for right age, not being in special education, school attendance, and post high school positive life choices have turned out to be the important outcomes. It has taken some time to figure out what to hope for and what to measure.

Taking a cue from Head Start, some character education programs have applied one of the important lessons learned from Project Head Start-the importance of community involvement in designing and implementing the program. But character education also needs to experiment with ideas for interventions, and to establish a research program to learn from educational practice. There are many ideas for educational programs. Books by Lickona (1991), Wynne \& Ryan (1993/1997), Damon (1995), the Kohlberg group (Power, Higgins, \& Kohlberg, 1989), contributors to Molnar (1997), as well as programs described in the Leming (1993) review (and others) make many suggestions about what might be tried. The problem is not with initial ideas for interventions. The problem is knowing what works. For instance, Bennett (1993) claims that exposure to moral heroes in stories is good for children. This idea certainly has intuitive appeal, and Bennett's books have been runaway bestsellers. However, Leming has this to say:

Those interested in character education have long believed that morally inspiring literature should be a part of any character education program. Surprisingly, not one research study has attempted to assess whether reading such literature has the expected effect on character. (1993, p. 69)

What we don't have is any systematic way to discover which interventions work with which children under which conditions. Without systematic research, we are like a physician who takes a patient to a pharmacy and says, "All these drugs are believed to help some people some of the time; take a bunch of them in any order, in any combination, and try them out." Head Start began with a flurry of activity and spent millions of dollars. But in its first years, no one really knew whether the program made a difference in the lives of the children it was supposed to help. Now, many years later, we have a good idea of what makes a successful preschool program and can document its long-term benefits (e.g., Zigler \& Styfco, 1994; Washington \& Bailey, 1995).

We are not advocating simple pragmatism: that is, searching empirically for "what works" and then doing whatever it is that "works." Parenthetically, some of the "effective schooling" literature seems to follow this approach. Instead, we are advocating that much research is necessary for theory-building; the general theories now predominant about general human nature are too blunt and global to adequately direct moral education interventions. We need research to guide the construction of more fine-tuned theories about moral education. This is the essential lesson from Head Start: that global theories about human nature are not sufficient for childhood interventions, and that more adequate theories about human development need to build on the basis of empirical research.

In summary so far, we contend that there is a vast spectrum of concerns about personality and social development of which we need to be aware (ranging from primary socialization that addresses youth violence to participation in community service programs that fosters responsible citizenship in a democracy). Many intervention ideas might be helpful for some youth some of the time under some conditions. What we don't have in place is a systematic way of tracking the effects of various interventions, thus providing a more factual base (rather than relying solely on ideology) and providing leads for further theory building. This is especially a problem for the early aspects of the moral development continuum.

\section{Defining Researchable Variables}

Now we will go further out on a limb and suggest that the greatest single impediment to establishing a solid research base is what we call "The Tripartite View." This tripartite view assumes that the basic elements in morality are these: affect, cognition, and behavior. Accordingly, the variables to study in research programs are conceptualized in terms of (a) feelings, motivations, and emotions; (b) reasoning, cognitions, and thinking; and (c) outward, observable behaviors and actions. Presumably, psychodynamic psychologists study feelings and affect, cognitive developmentalists study moral reasoning, and behaviorists and social learning psychologists study behavior and action. The usual measures and variables coming from these theoretical traditions are guilt, shame, and self-esteem (psychodynamic psychologists); stages of moral reasoning (Kohlberg/ Piaget); resistance to temptation, aggression, helping, and prosocial behaviors (behaviorists and social learning theorists).

In examining the origins of the tripartite view, it is interesting to notice that the view emerged not as a result of theorizing about the elements that give rise to moral behavior, but rather following a 1965 review of the psychodynamic, cognitive-developmental, and behavioral approaches to morality. Roger Brown (1965) gave psychological respectability to the tripartite view (see especially pp. 407-414). However, he pointed out that the major variables of the three approaches (feelings, thoughts, and behaviors) were not highly intercorrelated (or even highly correlated within themselves across situations and measures). In the ensuing 20 years, the tripartite view has reverberated throughout the literature. For instance, Lickona (1991) in one of the best recent compendiums of practical tips for teachers states, "Character ... has three interrelated parts: moral knowing, moral feeling, and moral behavior. Good character consists of knowing good, desiring the good, and doing the good ..." (p. 51). This line of argument continues for 10 pages, including a figure that has three circles, "Moral knowing," "Moral feeling," and "Moral action" (p. 53).

When psychologists assume the tripartite scheme and assume that these are the three basic elements, they usually 
don't find significant connections among the elements. Consequently, they are left with the conclusion that moral feelings don't have much to do with moral reasoning and that moral behavior is devoid of feeling and thinking. As long as we look for and study these variables, we will not progress in a research program.

Admittedly, there are things that could be said in favor of the tripartite scheme, and volumes have been written under the assumption that these are the basic elements. But consider for a moment the implications of working with the wrong set of elements. A brief quotation from a book on the history of science makes the point regarding the development of physics:

Aristotle's classic and incorrect theory [was] that all matter was made of four elements: fire, air, water, and earth. Each of these in turn was supposed to possess two of four basic properties: hot, cold, wet, and dry. ... Aristotle believed dry and cold united to form earth; cold and wet, water; wet and hot, air; hot and dry, fire. Formulated in the Fourth Century, B.C., the theory was embraced by all chemists and philosophers alike, and dominated and delayed the progress of science until the 17th Century. (Lapp, 1963, p. 12)

The tripartite view has hampered morality research by suggesting that there was a limited sort of cognition-affect interaction. But recent research has shown that there are many types of cognitions, many types of affects, and many kinds of observable behaviors involved in morality. Behavior judged as moral results from the internal interactions of cognitions and affects (e.g., Rest, 1983). Thus, there are no pure feelings completely devoid of cognitions, no cognitions completely devoid of affects, and all behavior is the result of cognitive-affective processes. Instead of trying to chop up morality into cognitions, affects, and behaviors, we suggest analyzing morality into the functional psychological processes that must arise to produce a moral behavior (See Rest, 1983; Rest, 1986; Rest \& Narvaez, 1994). We make no claim to have discovered the periodic table of elements for morality. But we do think it is more profitable for research to be based on these functional psychological processes than on the tripartite model.

\section{The Four Component Model}

Following is a list of basic component processes upon which we suppose morality is built. This list is subject to revision, but nevertheless, each component is supported by existing research (see Rest, 1983; Rest, 1986). In fact, research on these components of morality and their interactions has been conducted at the professional school level since the early 1980s (see Rest \& Narvaez, 1994). Recently, Narvaez and colleagues received funding for an application of the model for middle school students. ${ }^{5}$ We believe that the early phases of moral education will likewise benefit from a comprehensive approach to research and education that gives attention to each of the component processes.

1. Moral sensitivity: (interpreting the situation)

Moral sensitivity is the awareness of how our actions affect other people. It involves being aware of the different possible lines of action and how each line of action could affect the parties concerned (including oneself). Moral sensitivity involves imaginatively constructing possible scenarios (often from limited cues and partial information), knowing cause-consequent chains of events in the real world, and having empathy and roletaking skills. Moral sensitivity is necessary to become aware that a moral issue is involved in a situation.

2. Moral judgment: (judging which action is morally right or wrong)

Once a person is aware that various lines of action are possible, one must ask which line of action is more morally justified. This is the process emphasized in the work of Piaget (1932/1965) and Kohlberg (1984). Even at an early stage, people have intuitions about what is fair and moral, and make moral judgments about even the most complex of human activities. The psychologist's job is to understand how these intuitions arise and what governs their application to real-world events.

3. Moral motivation: (prioritizing moral values over other personal values)

People have many values (e.g., careers, affectional relationships, aesthetic preferences, institutional loyalties, hedonistic pleasures, excitement). Why place a high priority on moral values over these other values? Some evil people in the world (e.g., the professional assassin) may be explained not in terms of deficiencies in Components 1 and 2, but in terms of the low priority given to moral values. We don't have to infer that the assassin is deficient in terms of Component 1 (i.e., that he doesn't realize that shooting someone affects his/her welfare), nor do we have to infer that the assassin is deficient in terms of Component 2 (i.e., that he doesn't understand that cooperative arrangements have conditions of reciprocity). Rather, we are more likely to explain the assassin in terms of his values (i.e., he just doesn't care to do the fair, decent thing-other values are more important to him).

4. Moral character: (having the strength of your convictions, having courage, persisting, overcoming distractions and obstacles, having implementing skills, having ego strength)

A person may have the first three components (be sensitive to moral issues, have good judgment, prioritize moral values), but if he or she is lacking in Component 4 , the person will wilt under pressure or fatigue, won't follow through, will be distracted or discouraged, and moral behavior will fail. Component 4 presupposes that one has set goals, has self-discipline and controls impulse, and has the strength and skill to act in accord with one's goals.

This Four Component Model implies that all four processes of morality need to be fostered. Notice that we are not suggesting a linear decision-making model (see Rest, 1983, pp. 569-570). In fact, naturalistic decision-making may be neither logical, linear, interactive, nor deliberate. We also are not wed to just four components. In fact, some researchers have suggested subdividing some of the components into two or more separate constructs and variables (e.g., Bredemeier \& Shields, 1994; Higgins, 1992). Nor are we wed to assessing only one level of abstraction within a component. For example, Strike (1982) argued that professionals with a good grasp of abstract moral schemas, measured by tests of moral judgment (Component 2), may nonetheless lack an adequate grasp of specific (less abstract) 
intermediate concepts (e.g., informed consent, confidentiality, due process, etc.) that apply to their profession. Further, professionals may lack a grasp of the concrete rules and codes that serve as minimal performance expectations. Instruction and assessment, he proposed, must be directed toward each level of abstraction. Following Strike's lead, Bebeau and Thoma (1998; in press) explored the role of ethics education and moral judgment development on acquisition of intermediate ethical concepts and transfer to novel problems. To assure the integrity of a measure of intermediate concepts, professionals were extensively involved in the generation of stimulus cases and response alternatives. Construct validity was illustrated by high levels of agreement among dental ethicists as to better and worse actions and justifications for problems presented on the test, by significant differences among groups expected to differ in ethics expertise, and by educational intervention effects. Consistent with Strike's hypothesis, instruction facilitated performance on familiar problems, but transfer to novel problems depended upon acquisition of the moral schemas measured by a test of moral judgment.

The value of the Four-Component framework lies in its usefulness for understanding the reasons for moral failing, thus enabling the educator to design more effective educational experiences, and the researcher to generate researchable variables. Bebeau (1994) summarizes 15 years of programmatic research to design and validate assessment methods and instructional procedures for a professional ethics curriculum. Adequate functioning in all four components is the goal of the program. Measures (set in the context of real-life professional decision-making) are designed to evaluate student competence in each of the components and to illustrate the effectiveness of the school's instructional program. Validation of each assessment method involves determining what experts in the field regard as more defensible. By making both the criteria and standards for judgments explicit-following a process not unlike that used for establishing a Common Morality (Beauchamp \& Childress, 1994) - both the profession and the public can judge the adequacy of professional performance.

Recently, Bebeau (1997) described how validated measures of each of the components were used to assess 22 professionals referred for ethics instruction by the Board of Dental Examiners because of violations of the state practice act. For each licensee, data from performance-based assessments, when compared with professional norms for performance, illuminated specific deficiencies that appeared to give rise to particular moral failings. Each licensee showed a deficiency in his or her understanding of the role of the professional in contemporary society (the moral identity dimension of moral motivation-Component 3 ), and each licensee showed deficits in at least one other component. Interventions were designed to address particular deficits, and license reinstatement was contingent upon performance improvements. The effectiveness of the intervention was also supported by participants' views that instruction enabled them to engage in more reflective decision-making. The main point we wish to make is to urge that the elements, by which we track the impact of moral interventions, be characterized not in terms of the usual tripartite scheme, but in terms of the functional units for producing moral behavior.
The Four Component Model provides a way to approach what might be called "the criterion problem." ${ }^{\prime}$ That is, how do we know "what works" in moral education? What is it that is supposed to be improved when we have a success in moral education? In other words, what are the criteria for success?

Various criteria have been used to evaluate moral education programs: decrease in drug abuse, fewer drive-by shootings, less school vandalism, less cheating at the Naval Academy, more engineers and mathematicians for our nation's defense, greater participation in elections of public officials, greater confidence in our political and corporate leaders, more volunteerism in the community,

\section{Striking parallels can be drawn between the current emphasis on "the basics" through character education and the beginning of the Head Start preschool education program ...}

etc. We don't wish to ridicule the importance of such criteria, however, such lists are post hoc and subject to changes in the public perception of need. Because of the constantly changing context and interpretation of the "needs of the day," we do not think that an ongoing research program for moral education should be linked to "pay-offs" like these. Instead, we advocate regarding increases on each of the Four Components as criteria for successful moral education programs. That is, the criterion for judging whether a moral education intervention is "working" or not is assessed in terms of improvements in moral sensitivity, judgment, motivation, and character. The program that produces greater gains on each of these Four Components is the better program.

The Four Components are proximal criteria of moral education interventions, rather than ultimate criteria (like decreased crime rates or better citizenship). The Components are psychological processes likely to register the effects of moral education, rather than long-range, multiplydetermined, gross effects. Just as Head Start was oversold as "the cure for poverty" (an ultimate criteria) and later assessed in terms of more proximate criteria (such as participants' need for remedial social services), so also the Four Components are more proximal and researchable criteria.

Whereas the Four Components define the particular process that will be elicited in the context of decisionmaking, researchers and educators in each educational setting must decide on the range of problems and situations they will present to assess competence in context. Involving members of the community in the assessment development process and using the community to establish standards for judging performance will raise the intellectual and moral standards of educational settings and communicate expectations to students. At each developmental level of education, community members can engage in a deliberative process to determine (a) better and worse interpretations of 
moral issues (ethical sensitivity); (b) better and worse justifications for actions (moral judgment); (c) expectations for behavior in particular contexts, for example, "the good student," "the good citizen," "the good husband," or "the good professional," (moral identity) and indicators of commitment to moral ideals; as well as (d) indicators to judge courage, persistence, and follow through (moral character) and prototypes for effective responses to problematic contexts (e.g., "just say no"). For an especially rich example of the way problematic contexts and prototypic responses can be used to help delinquent adolescents develop impulse control and practice social skills, see Gibbs, Potter, and Goldstein (1995).

\section{The Four Component Model and Moral Education Programs}

The Four Component Model is useful in comparing different approaches to moral education. Approaches differ in which process of the Four Component Model is emphasized, in their main social goals, and in targeting different groups for the interventions. Several examples will illustrate this diversity: (a) The dilemma discussion approach promoted by Kohlberg's earlier writings emphasizes Component 2, the development of moral judgment (Reimer, Paolitto \& Hersh, 1983). This approach is still a major technique used especially with students in college and professional schools. Here the main social concern is to prepare professionals to make decisions that will be morally defensible. ${ }^{7}$ It is also used successfully with violent offenders in Aggression Replacement Training (e.g., Goldstein \& Glick, 1994) and in alternative schools, high schools, and other secondary education programs (Mosher, 1980). (b) The traditional character education approach (e.g., Wynne \& Ryan, 1993 / 1997) emphasizes Component 4, the development of impulse control and self-discipline consistent with living in civilized society. Younger children, especially those prone to delinquency, are the special targets. A primary concern is to eliminate the destructive behavior of youth (e.g., violence, drugs, pregnancy). (c) Sensitivity approaches (e.g., Gropper, 1996) emphasize Component 1 . The sensitivity approaches (e.g., sensitivity training for improved face-to-face communication, sensitivity to cultural diversity, sensitivity to sexual harassment, sensitivity to physical and psychological abuse, anti-bias curricula) are aimed at all ages. (d) The Communitarian Approach (e.g., Etzioni, 1993) suggests that students (usually junior and senior high school students) be involved in community service. The main social concern is to strengthen ties to larger social units than just the family. In emphasizing the importance of rootedness to community, this approach is aimed at Component 3-to shift focus from highly individualistic (and selfish) values towards communitarian values. Although many moral education programs address at least one of the four components, it is rare to find education programs that encompass all four. For examples of professional education programs designed to promote each of the components, see Bebeau (1994) and Duckett and Ryden (1994). For examples of programs in early education or treatment of antisocial youth that address more than one component, see Battistich, Watson, Solomon, Schapps, and Solomon (1991), or Gibbs, Potter, and Goldstein (1995). The latter, the EQUIP program, not only addresses functional processes that give rise to moral- ity, but also satisfies an important eternal criterion for moral education-reduced recidivism of delinquent adolescents.

\section{Moral Knowledge and the Four Component Model}

The Four Component Model helps us relate the various kinds of moral knowledge to effective moral functioning. For example, William Bennett, one of the best known proponents of character education, writes (1993): “[Children] must achieve at least a minimal level of moral literacy. ... If we want our children to possess the traits of character we most admire, we need to teach them what those traits are and why they deserve both admiration and allegiance" (p. 11). The two ideas stressed here are that moral knowledge is at the core of the psychology of morality, and that socializers must directly teach the moral knowledge they want children "to possess."

Regarding the second point first- the role of direct teaching-many diverse interventions have been suggested: reading about moral exemplars, incorporating practice and habit, encouraging discussion and exploration, providing service experiences, and including social reinforcers. How do we know these strategies are effective? For whom and under what conditions are these effective? Presently, we simply don't have the research to inform us when and with whom a certain intervention is appropriate. We don't deny the commonsensical notion that reading moral stories to children and telling children what is right and wrong has a place in moral education-but it is not clear when it is helpful and when it is not (see Leming, 1993). Recent research (Narvaez, Bentley, Gleason, \& Samuels, 1998; Narvaez, Gleason, Mitchell, \& Bentley, in press) indicates that reading moral stories to children does not necessarily convey the intended moral lesson.

Regarding the point that "moral knowledge" is the key to developing the moral person, the existing psychological literature (Rest, 1983; 1986) indicates that "moral knowledge" is not one single unitary thing. To help make the point about the complexity of "moral knowledge," consider the following example: Suppose we want to teach the virtue of moral courage. We instruct the child to stand up for what he/she thinks is right, even when acting so is met with social disapproval. Then the child hears about the Oklahoma City bombing. Why wasn't this an act of moral courage?

The Four Component Model directs us to consider the various kinds of moral knowledge (declarative, semantic, procedural, representational) required for effective moral functioning. For example, the type of knowledge required to figure out the moral ramifications of performing certain acts (Component 1 ) is different from the knowledge required to judge which action alternative is morally justifiable (Component 2), which, in turn, is different from the moral knowledge involved in prioritizing moral goals ahead of other valued goals (Component 3 ), which, in turn, is different from the kinds of moral knowledge required to keep the goal clearly in mind, to resist distraction and fatigue, and to invoke subroutines needed to work around impediments (Component 4). While all four components involve moral knowing in some sense, they invoke qualitatively different cognitive processes. Researchers studying these processes use different operations to assess each one and use different theories to explain their functioning (Rest, 1983). The problem with the tripartite model is that it fails 
to distinguish the kinds of knowing required for effective moral functioning.

\section{Summary}

In conclusion, let us learn from the Head Start preschool movement. Just to engage in a flurry of activity will not advance our understanding of the complexities of the processes, nor provide documentation as to what works best with whom under which conditions. We must be mindful that there are many concerns with regard to socialpersonality development, and that the current concerns with violence, drugs, and pregnancy are not the only concerns. Today attention may be focused on basic socialization, though any day an event could shift attention to another part of the developmental spectrum. And so, while we do not wish to minimize the present concern over youth destructiveness, we do want to make the point that there are problems at all levels of development and education. We need to advance moral development and character development for all our citizens. To accomplish a broad-based approach to moral education, we suggest that the establishment of systematic research necessitates moving away from the view that the three basic elements to study are moral reasoning, feelings, and moral behavior. We suggest that we set up a research system that analyzes interventions in terms of the functional psychological processes that give rise to morality (as suggested by the Four Component Model).

\section{Notes}

Correspondence concerning this article should be addressed to Muriel J. Bebeau, Department of Preventive Sciences, School of Dentistry, University of Minnesota, 15-136 Moos Tower, 515 Delaware Street Southeast, Minneapolis, MN 55455. Electronic mail may be sent via Internet to bebea001@maroon.tc.umn.edu.

${ }^{1}$ In 1996, two conferences were held by the military to explore character development of military personnel. The first, held in March in Chicago, IL, brought together public representatives and representatives from each branch of service to explore the role of character education in assuring a moral-ethical officer corp. The second, held in May in Atlanta, GA, brought together Army personnel and selected public representatives to create a character education plan for all Army personnel. As a result of the process, the Army education system created a set of core values, widely publicized in 1998, and subsequently integrated into the Army education system. Basic Training was extended from eight to nine weeks to accommodate the values training. The Air Force and Navy in recent years have also established core values programs whose purposes are to encourage behavior in accordance with service requirements and traditions and to strengthen the character of individual service members.

${ }^{2}$ Turiel challenges the repeatedly stated assumptions of a moral decline. He points out "vast societal changes over the past two centuries ... make it very difficult to document whether there has been decay, improvement, or simply patterns of positive and negative changes associated with different realms of social life" (Turiel, 1998, p. 874).

${ }^{3}$ Zigler writes:

During the early twentieth century, there was a period in the treatment of retarded children when the notion of "mental orthopedics" was in ascendancy. Many workers felt that, given the right kind of experience and training, retarded children might become "normal." Soon state schools were set up to provide the training that would ultimately "cure" retardation. When the retarded children did not become normal, these schools simply gave up on any attempt at treatment. They became purely custodial institutions, and the treatment of retarded persons entered its darkest phase. My concern was that Head Start might suffer a similar fate, that overoptimism might lead to undue pessimism. Then the nation might be even less willing to help poor children than it had been before Head Start began. (Zigler \& Muenchow, 1992, p. 53)

${ }^{4}$ For instance, Kilpatrick (1992) in his first chapter (pp. 13-16) explains the title of his book, Why Johnny Can't Tell Right From Wrong.
Kilpatrick argues that the problem of morality is similar to the problem in teaching reading. Back in the 1950s, Flesch in his bestseller, Why Johnny Can't Read, had argued that the current reading problems of children were due to a faulty method of teaching; teachers were to blame for having abandoned a tried-and-true method of reading for a new, faulty method of teaching reading. So also, Kilpatrick argues, moral literacy is a problem because teachers have abandoned a triedand-true method of teaching morals. Leftist schools of education and lazy teachers have shifted from good teaching methods (for morals) to bad teaching methods. In both cases (for literacy-according to Flesch, and moral literacy-according to Kilpatrick), the solution is for teachers to return to the earlier, better teaching method.

${ }^{5}$ Under the auspices of a four-year Character Education Partnership grant from the federal government to the state of Minnesota, Narvaez and colleagues (1999) are creating guidelines for teachers to incorporate moral education into curricula that meet graduation standards. Focusing on the teachable aspects of each component, the guidelines use an expertise-development structure and are based on both the four-component model and state-wide, community input (a commonmorality approach).

${ }^{6}$ Notice that the Four Component Model does not resolve the question of "whose values." But, neither does the modern application of Virtue theory. There is no simple answer to this question. While it may be possible to achieve an appearance of consensus by sticking with an abstract list of traditional virtues (e.g., Lickona's 4th and 5th Rs, "respect and responsibility" [1991]), such a consensus is superficial at best. What is respectful conduct in one culture may not be respectful in another culture. What is responsible conduct in one context is not responsible in another. Cloning, for example, was not an issue in Aristotle's time. In our view, this aspect of the criterion question is never ending; it varies from time to time and from context to context. The best we can do is to develop specific assessments (based on one or more of the Four Components) for particular contexts and then attempt to achieve consensus within a given community (e.g., a profession) to discriminate better from worse performance.

${ }^{7}$ For an extensive discussion of current thinking regarding the application of moral theory to moral decision-making, see Beauchamp and Childress (1994) regarding professional ethical development and Pritchard (1996) regarding children's moral development. Both De Grazia (1992) and Toulmin (1981) argue against foundational principlism (advocated by Kohlberg [1984] and other philosophers of his time), and for an inductive approach that uses existing social agreements and practices as a starting point for arriving at solutions to the moral diversity that confronts us. For an extensive discussion of the psychological and philosophical criticisms of the cognitive-developmental approach to the study of moral judgment, and a response that addresses these criticisms, see Rest, Narvaez, Bebeau, and Thoma (1999). These authors propose a neo-Kohlbergian view of development that is not grounded in a particularistic philosophical theory, yet maintains the essential features of an empirically grounded theory of moral judgment development.

\section{References}

Battistich, V., Watson, M., Solomon, D., Schaps, E., \& Solomon, J. (1991). The child development project: A comprehensive program for the development of biosocial character. In Kurtines, W., \& Gewirtz, J. (Eds.), Handbook of moral behavior and development: Application: Vol. 3. (pp. 1-34). Hillsdale, NJ: Erlbaum.

Beauchamp, T. L., \& Childress, J. F. (1994). Principles of biomedical ethics (4th ed.). New York: Oxford University Press.

Bebeau, M. J. (1994). Influencing the moral dimensions of dental practice. In J. R. Rest \& D. Narvaez (Eds.), Moral development in the professions: Psychology and applied ethics (pp. 121-146). Hillsdale, NJ: Erlbaum.

Bebeau, M. J. (1997). Continuing ethics education for remediation. Paper presented at the meeting of the American Association of Dental Schools, Orlando, FL

Bebeau, M. J., \& Thoma, S. J. (in press). Intermediate concepts and the connection to moral education. Educational Psychology Review.

Bebeau, M. J., \& Thoma, S. J. (1998, April). Designing and testing a measure of intermediate level ethical concepts. Paper presented at the annual meeting of the American Educational Research Association, San Diego, CA.

Bennett, W. J. (1991). Moral literacy and the formation of character. In J.S. Benninga (Ed.), Moral, character, and civic education in the elementary school (pp. 131-138). New York: Teachers College Press. 
Bennett, W. J. (Ed.) (1993). The book of virtues. New York: Simon \& Schuster.

Bennett, W. J. (Ed.) (1995a). The children's book of virtues. New York: Simon \& Schuster.

Bennett, W. J. (Ed.) (1995b). The moral compass. New York: Simon \& Schuster.

Boston University (1993). The art of loving well: A character education program for today's teenagers. Boston: Boston University School of Education.

Bredemeier, B. J. L., \& Shields, D. L. L. (1994) Applied ethics and moral reasoning in sport. In J. R. Rest \& D. Narvaez (Eds.), Moral development in the professions: Psychology and applied ethics (pp. 173-187). Hillsdale, NJ: Erlbaum.

Brown, R. (1965). Social psychology. New York: The Free Press.

Charney, R. (1992). Teaching children to care: Management in the responsive classroom. Greenfield, MA: Northeast Foundation for Children.

Clouser, K. D., \& Gert, B. (1990). A critique of principlism. The Journal of Medicine and Philosophy, 15, 219-236.

Damon, W. (1995). Greater expectations: Overcoming the culture of indulgence in America's homes and schools. New York: The Free Press.

Damon, W. (1997). The youth charter: How communities can work together to raise the standards for all our children. New York: The Free Press.

De Grazia, D. (1992). Moving forward in bioethical theory: Theories, cases, and specified principlism. The Journal of Medicine and Philosophy, 17, 511-539.

De Roche, E. F., \& Williams, M. M. (1998). Educating hearts and minds: A comprehensive character education framework. Thousand Oaks, CA: Corwin Press

Duckett, L. J., \& Ryden, M. B. (1994). Education for ethical nursing practice. In J. R. Rest \& D. Narvaez (Eds.), Moral development in the professions: Psychology and applied ethics (pp. 51-69). Hillsdale, NJ: Erlbaum. Educational Leadership (1993, November). 51(3).

Etzioni, A. (1993). The spirit of community. New York: Crown.

Flesh, R. (1955). Why Johnny can't read. New York: Harper Colophon Books.

Gibbs, J. C., Potter, G. B., \& Goldstein, A. P. (1995). The EQUIP Program: Teaching youth to think and act responsibly through a peer-helping approach. Champaign, IL: Research Press.

Goldstein, A. P., \& Glick, B. (1994). Aggression replacement training: Curriculum and evaluation. Simulation and Gaming, 25, 9-26.

Gropper, R. C. (1996). Culture and the clinical encounter: An intercultural sensitizer for the health professions. Yarmouth, ME: Intercultural Press.

Guttmann, A., \& Thompson, D. (1997). Democracy and disagreement. Cambridge, MA: Harvard University Press.

Hartshorne, H., \& May, M. (1928-1930). Studies in the nature of character. (Vols. 1-3). New York: Macmillan.

Herbert, R. (1996, June 3). The moral child. U.S. News and World Report, $120(22), 52-58$.

Higgins, A. (1992). The development of morality: An overview from 1983 to 1991. NERA Researcher, 30(3), 2-6.

Iovine, J. V. (1997, March 1). The discipline dilemma. Minneapolis Star Tribune, pp. E1, E4.

Kilpatrick, W. (1992). Why Johnny can't tell right from wrong. New York: Simon \& Schuster.

Kirschenbaum, H. (1995). One hundred ways to enhance values and morality. Needham Heights, MA: Allyn \& Bacon.

Klein, J. (1994, June 13). Learning how to say no: Clinton's new teenpregnancy program will counsel abstinence. Newsweek, 123(24), 29.

Kohlberg, L. (1984). The psychology of moral development: Essays on moral development (Vol 2). San Francisco: Harper \& Row.

Kohn, A. (1997) How not to teach values: A critical look at character education. Phi Delta Kappan, 78(6), 429-439.

Lapp, R. E. (1963). Matter. New York: Time, Inc.

Leming, J. (1993, November). In search of effective character education. Educational Leadership 51(3) 63-71.

Leming, J. S. (1997). Research and practice in character education: A historical perspective. In A. Molnar (Ed.), The construction of children's character. Chicago: University of Chicago Press.

Leming, J. S., Henricks-Smith, A., \& Antis, J. (1997, March). An evaluation of the Heartwood Institute's "an ethics curriculum for children." Paper presented at the annual meeting of the American Educational Research Association, Chicago, IL.

Lickona, T. (1991). Educating for character. New York: Bantam.

Molnar, A. (Ed.) (1997). The construction of children's character. Chicago: University of Chicago Press.

Mosher, R. L. (Ed.). (1980). Moral education: A first generation of research and development. New York: Praeger.
Narvaez, D., Bentley, J., Gleason, T., \& Samuels, S. J. (1998). Moral theme comprehension in third grade, fifth grade and college students. Reading Psychology, 19(2) 217-241.

Narvaez, D., Gleason, T., Mitchell, C., \& Bentley, J. (in press). Measuring moral cognition in children using moral theme comprehension. Journal of Educational Psychology.

Narvaez, D., Mitchell, C., Bock, T., Endicott, L., \& Gardner, J. (1999). Guidelines for developing curricula for middle school students that meet graduation standards while teaching character. Book in preparation.

Piaget, J. (1965). The moral judgement of the child. (M. Gabain, Trans.). New York: The Free Press. (Original work published 1932)

Power, F. C., Higgins, A., \& Kohlberg, L. (1989). Lawrence Kohlberg's approach to moral education. New York: Columbia University Press.

Pritchard, M. S. (1996). Reasonable children: Moral education and moral learning. Lawrence, KS: University Press of Kansas.

Reimer, J., Paolitto, D. P., \& Hersh, R. H. (1983). Promoting moral growth: From Piaget to Kohlberg (2nd ed.). New York: Longman.

Rest, J. R. (1983). Morality. In P. H. Mussen (series Ed.), J. Flavell \& E. Markman (Vol. Eds.), Handbook of child psychology: Cognitive development: Vol. 3 (pp. 556-629). New York: Wiley.

Rest, J. R. (1986). Moral development: Advances in research and theory. New York: Praeger.

Rest, J. R., \& Narvaez, D. (Eds.). (1994). Moral development in the professions: Psychology and applied ethics. Hillsdale, NJ: Erlbaum.

Rest, J., Narvaez, D., Bebeau, M. J., \& Thoma, S. J. (1999). Postconventional moral thinking: A neo-Kohlbergian approach. Mahwah, NJ: Laurence Erlbaum.

Strike, K. A. (1982). Educational policy and the just society. Chicago: University of Illinois Press.

Toulmin, S. (1981). The tyranny of principles. Hastings Center Report, 11, 31-39.

Turiel, E. (1998). The development of morality. In W. Damon (Ed.), Handbook of child psychology: Vol. 3 (5th ed). In N. Eisenberg (Ed.), Social, emotional, and personality development. New York: Wiley.

Walzer, M. (1983). Spheres of justice. New York: Basic Books.

Washington, V., \& Bailey, U. J. (1995). Project Head Start: Models and strategies for the twenty-first century. New York: Garland.

Wynne, E., \& Ryan, K. (1997). Reclaiming our schools: A handbook on teaching character, academics and discipline. New York: Merrill. (Original work published 1993)

Zigler, E., \& Muenchow, S. (1992). Head Start: The inside story of America's most successful educational experiment. New York: Basic.

Zigler, E., \& Valentine, J. (Eds.). (1979). Project Head Start: A legacy on the war on poverty. New York: The Free Press.

Zigler, E., \& Styfco, S. J. (1994). Head Start: Criticisms in a constructive context. American Psychologist, 49(2), 127-132.

Manuscript received June 23, 1997

Revision received February 3, 1998

Accepted February 6, 1998

\section{Future AERA Annual Meetings}

2000: New Orleans, April 24-28

2001: Seattle (tentative), April 10-14

2002: New Orleans (tentative), April 1-5

2003: Chicago, April 21-25 